\title{
MAPPINGS CONNECTED WITH HERMITE-HADAMARD INEQUALITIES FOR SUPERQUADRATIC FUNCTIONS
}

\begin{abstract}
S. BANIĆ
Abstract. Using some characterizations of superquadratic functions we obtain some results on two mappings $H$ and $F$ connected with Hermite-Hadamard inequality. Our results generalize corresponding results for convex functions. Especially, when the superquadratic function is convex at the same time, then our results represent also the refinements of those results.

Mathematics subject classification (2000): 26D15.

Keywords and phrases: Hermite-Hadamard inequality, convex functions, superquadratic functions.
\end{abstract}

\section{REFERENCES}

[1] S. Abramovich, S. Banić, M. Matić, Superquadratic Functions in Several Variables, J. Math. Anal. Appl., 327, 2 (2007), 1444-1460.

[2] S. Abramovich, G. Jameson and G. Sinnamon, Refining Jensen's Inequality, Bull. Math. Soc. Sci. Math. Roumanie (N.S.), 47, 95 (2004), no. 1-2, 3-14.

[3] S. Abramovich, G. Jameson And G. Sinnamon, Inequalities for Averages of Convex and Superquadratic Functions, JIPAM, 5, 4 (2004), Article 91, 14 pp. (electronic).

[4] M. AKKouchi, A Result on the Mapping H of S.S. Dragomir with Applications, Facta Univ. Ser. Math. Inform., 17 (2002), 5-12.

[5] S. BAnić, J. PeČARIĆ, S. VARoŠAnec, Superquadratic Functions and Refinements of Some Classical Inequalities, J. Korean Math. Soc., 45, 2 (2008), 513-525.

[6] S. Banić, S. VARošAnec, Functional Inequalities for Superquadratic Functions, Int. J. Pure Appl. Math., 43, 4 (2008), 537-549.

[7] Y. J. Cho, M. Matić, J. PeČARIĆ, Two Mappings in Connection to Jensen's Inequality, Panamer. Math. J., 12, 1 (2002), 43-50.

[8] S. S. Dragomir, Two Mappings in Connection to Hadamard's Inequalities, J. Math. Anal. Appl., 167, 1 (1992), 49-56. 